\title{
Rhodium-Catalyzed Synthesis of Diaryl Sulfides Using $\mathrm{S}_{8}$ /Organopolysulfides
}

\section{Category}

Metal-Mediated

Synthesis

\section{Key words}

rhodium

sulfur

aryl fluorides

diaryl sulfides<smiles>Fc1c(F)c(F)c(F)c(F)c1F</smiles>

quiv)

$t$-BuSSSSBu- $t$ ( 0.9 equiv) (conditions B) $\mathrm{RhH}\left(\mathrm{PPh}_{3}\right)_{4}(5 \mathrm{~mol} \%)$

$\mathrm{dppBz}(10 \mathrm{~mol} \%)$

$n-\mathrm{Bu}_{3} \mathrm{SiH}(100 \mathrm{~mol} \%)$

$\mathrm{DMF}, 80^{\circ} \mathrm{C}$ or $25^{\circ} \mathrm{C}$

conditions B: $t$-BuSSSSBu- $t$ ( 0.9 equiv)

$\mathrm{RhH}\left(\mathrm{PPh}_{3}\right)_{4}(10 \mathrm{~mol} \%)$

$\mathrm{dppBz}(20 \mathrm{~mol} \%)$

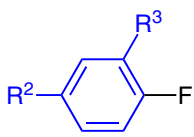

$n-\mathrm{Bu}_{3} \mathrm{SiH}(100 \mathrm{~mol} \%)$

DMF, $80^{\circ} \mathrm{C}$

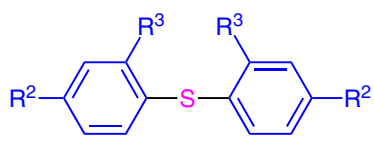

up to $66 \%$ yield

Selected examples:<smiles>O=[N+]([O-])c1c(F)c(F)c(Sc2c(F)c(F)c([N+](=O)[O-])c(F)c2F)c(F)c1F</smiles>

$42 \%$ yield (conditions $\mathrm{A}$ )<smiles>Fc1c(F)c(-c2ccccc2)c(F)c(F)c1Sc1c(F)c(F)c(-c2ccccc2)c(F)c1F</smiles>

$80 \%$ yield (conditions $\mathrm{B}$ )

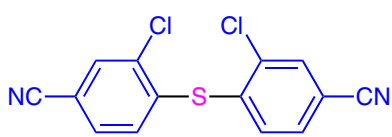

$53 \%$ yield (conditions $\mathrm{B}$ )<smiles>Nc1c(F)c(F)c(F)c(F)c1Sc1c(F)c(F)c(N(c2ccccc2)c2ccccc2)c(F)c1F</smiles>

$18 \%$ yield (conditions $A$ )<smiles>O=C(Oc1ccccc1)c1c(F)c(F)c(Sc2c(F)c(F)c(C(=O)Oc3ccccc3)c(F)c2F)c(F)c1F</smiles>

$71 \%$ yield (conditions $B$ )
Significance: The rhodium-catalyzed reaction of sulfur or organopolysulfides with aryl penta- and monofluorides in the presence of tributylsilane is disclosed. The corresponding diaryl sulfides are obtained in moderate to good yield.
Comment: The mechanism is proposed to proceed via oxidative addition of the rhodium complex to the aryl fluoride and the SS-SS bond. After insertion of one sulfur atom, di-tert-butyl trisulfide is expelled and the rhodium-fluoride-aryl sulfide complex reacts with another aryl fluoride. The fluoride atoms are trapped with tributylsilane or triphenylphosphine and the corresponding diaryl sulfides are obtained after reductive elimination.

SYNFACTS Contributors: Paul Knochel, Nadja M. Barl

Dol: 10.1055/s-0032-1317733; Reg-No.: P15512SF 